\title{
PENGGUNAAN STRATEGI INKUIRI DALAM PEMBELAJARAN KOOPERATIF UNTUK MENINGKATKAN HASIL BELAJAR SISWA KELAS VIII A DI SMPN I GENENG NGAWI TAHUN AJARAN 2008 / 2009
}

\author{
Andrias Marsanto \\ SMA N 1 Mejayan, Madiun \\ Email: andrias.marsanto@gmail.com \\ Diterima 5 Januari 2015 disetujui 14 Maret 2015
}

\begin{abstract}
Implementation of biology learning in SMPN 1 Geneng Ngawi using lecture method. so that student learning outcomes are still low. Results of preliminary observations of student activity to formulate the problem, formulate hypotheses, conduct experiments, collect data, draw conclusions have not been reached indicators ketercapaian.Tujuan research to improve student learning outcomes VIIIA grade SMP Negeri 1 Geneng Ngawi. Research methods using action research, research subjects 40 students VIIIA. Collecting data using achievement test, observation of activities of students and teachers in learning. The study was conducted in two cycles. The results showed an increase in learning outcomes of the first cycle to the second cycle, $33 \%$ formulate problems, formulate hipotesis $13 \%$, experiment $15 \%, 20 \%$ collect data, draw conclusions $7.5 \%$. Data student activity increased by $14 \%$. Data activities of teachers increased by $15 \%$. The conclusion of this research inquiry into the use of cooperative learning strategies can improve learning outcomes biology VIIIA grade students of SMPN 1 Geneng Ngawi with have significancy level.
\end{abstract}

Keywords: learning outcomes, inquiry, cooperative

\section{PENDAHULUAN}

Strategi mengajar merupakan suatu cara yang dilakukan oleh guru didalam proses belajar mengajar yang meliputi model pembelajaran, media yang tersedia, sumber pembelajaran dan sarana lain yang dapat menunjang proses pembelajaran. Selama ini guru belum berusaha maksimal dalam memilih strategi pembelajaran. Selama ini proses pembelajaran biologi masih banyak menggunakan paradigma lama.Guru mengajar dengan metode konvensional yaitu metode ceramah dan mengharapkan siswa duduk, diam, mencatat sehingga kegiatan belajar mengajar (KBM) menjadi kurang menarik perhatian siswa. Guru sebaiknya dapat membangkitkan semangat siswa untuk belajar. Menurut Wina Sanjaya (2006) peran guru adalah: sebagai sumber belajar, fasilitator, pengelola demonstarator, pembimbing evaluator. Guru dituntut lebih kreatif,inovatif agar proses KBM berjalan dengan baik.
Berdasarkan hasil pengamatan dan wawancara dengan guru biologi SMP Negeri 1 Geneng bahwa siswa klas VIII A belum dapat menerapkan dan menjalankan langkah-langkah strategi inkuiri dalam proses pembelajaran, hal ini ditunjukkan dengan beberapa bukti riil antara lain: siswa dalam merumuskan masalah menunjukkan 55\% dari 40 siswa mampu merumuskan masalah. Pengembangan kemampuan siswa dalam menguji, menggolongkan data, melihat dan merumuskan hubungan logis dan merumuskan hipotesis, siswa yang mampu melakukan hipotesis sebanyak $50 \%$ dari 40 siswa. Proses menganalisa data khususnya proses menentukan jawaban yang dianggap diterima sesuai dengan data atau informasi yang diperoleh belum optimal, sebanyak $45 \%$ dari 40 siswa yang mampu menganalisa data. Melakukan eksperimen kinerja siswa belum optimal $50 \%$ dari 40 siswa dapat melakukan eksperimen dengan mengikuti langkah-langkah dengan benar, siswa yang mampu merumuskan kesimpulan sebanyak 
$45 \%$ dari 40 siswa.

Nurhadi (2004) menyatakan bahwa pembelajaran kooperatif adalah pembelajaran yang secara sadar dan sengaja mengembangkan interaksi yang silih asuh, untuk menghindari ketersinggungan dan kesalahpahaman yang dapat menimbulkan permusuhan sebagai latihan hidup di masyarakat. Pembelajaran kooperatif merupakan pembelajaran yang memiliki ciri bahwa siswa belajar dalam kelompok secara kooperatif, kelompok dibentuk dari siswa-siswa yang memiliki latar belakang heterogen, dan pengharagaan lebih diutamakan pada kerja kelompok daripada perorangan. Pembelajaran kooperatif bertujuan untuk meningkatkan kinerja siswa dalam tugas-tugas akademik (Tatag Yuli Eko Siswono,2009).

Pembelajaran

kooperatif menciptakan interaksi yang asah dan asuh sehingga tercipta masyarakat belajar (learning community). Siswa tidak hanya belajar dari guru, tetapi juga dari sesama siswa. Pembelajaran kooperatif adalah pembelajaran yang secara sadar dan sengaja mengembangkan interaksi yang silih asuh untuk menghindari ketersinggungan dan kesalahpahaman yang dapat menimbulkan permusuhan sebagai latihan hidup di masyarakat (Sugiyanto, 2007). Tujuan penelitian untuk meningkatkan hasil belajar siswa di SMP Negeri 1 Geneng, Ngawi tahun ajaran 2008/2009 melalui strategi pembelajaran Inkuiri dalam setting kooperatif.

\section{METODE}

Penelitian menggunakan penelitian tindakan kelas (PTK). Pelaksanaan pengumpulan data dalam penelitian dilakukan dalam setiap siklus, setiap putaran (siklus) terdiri dari perencanaan (planning), tindakan (acting), pengamatan (observing) dan refleksi (reflecting). Subjek penelitian siswa VIII SMP Negeri 1 Geneng, jumlah 40 siswa. Sumber data dalam penelitian adalah 1) data inkuiri, 2) merumuskan masalah, 3) merumuskan hipotesis, ketiga data tersebut diambil menggunakan tes, 4) data melakukan eksperimen, diambil melalui observasi, 5) mengumpulkan data, 6) menarik kesimpulan, keduanya diambil menggunakan tes, 7) data kualitas pembelajaran guru diambil dengan melalui observasi. Pencapaian indikator kegiatan siswa secara klasikal dihitung dengan menggunakan rumus:

Pencapaian klasikal $=\frac{\sum \text { siswa yang minimal mendapat predikat baik }}{\sum \text { siswa }} \mathrm{Xl} 0 \% \%$

Skor yang didapat dinyatakan dalam bentuk rentangan, sebagai berikut.

$$
\begin{aligned}
& \mathrm{A}=76 \%-100 \% \text { (Sangat baik) } \\
& \mathrm{B}=51 \%-75 \% \quad \text { (Baik) } \\
& \mathrm{C}=26 \%-50 \% \quad \text { (Cukup) } \\
& \mathrm{D}=0 \%-25 \% \text { (Kurang) }
\end{aligned}
$$

\section{HASIL DAN PEMBAHASAN}

Berdasarkan hasil penelitian, diperoleh data-data hasil inkuiri siswa yang meliputi: 1) merumuskan masalah pada siklus pertama $55 \%$ dan pada siklus kedua $88 \%, 2$ ) merumuskan hipotesis pada siklus pertama $70 \%$ dan pada siklus kedua $88 \%$, 3) melakukan eksperimen pada siklus pertama $80 \%$, dan pada siklus kedua $95 \%, 4)$ mengumpulkan data pada siklus pertama $70 \%$ dan pada siklus kedua $90 \%$, 4) merumuskan kesimpulan pada siklus pertama $82,5 \%$ dan pada siklus kedua $90 \%$. Data kualitas pembelajaran yang diambil dengan observasi aktivitas siswa diperoleh siklus pertama $78 \%$ dan pada siklus kedua 92\%. Data kualitas pembelajaran yang diperoleh melalui observasi aktivitas guru siklus pertama $70 \%$ dan siklus kedua $85 \%$.

Hasil penelitian di atas disajikan dalam tabel yaitu Data aktivitas siswa dalam pembelajaran terdapat Tabel 1 dan data aktivitas guru dalam pembelajaran yang ditunjukkan pada Tabel 2 . 
Tabel 1.Data aktifitas siswa dalam pembelajaran

\begin{tabular}{|c|c|c|c|c|c|c|}
\hline \multirow{2}{*}{ Aspek yang dinilai } & \multicolumn{4}{|c|}{ Kriteria Penilaian } & \multirow{2}{*}{ Skor } & \multirow{2}{*}{$\begin{array}{c}\text { Skor } \\
\text { Maksimal }\end{array}$} \\
\hline & 4 & 3 & 2 & 1 & & \\
\hline \multicolumn{7}{|l|}{ Kegiatan Awal } \\
\hline 1.Mempersiapkan alat dan bahan / materi & 4 & & & & 4 & 4 \\
\hline 2. Kondisi siswa & 4 & & & & 4 & 4 \\
\hline \multicolumn{7}{|l|}{ Kegiatan Inti } \\
\hline 1.Aktif dalam kelompok & 4 & & & & 4 & 4 \\
\hline 2.Suasana kelas & & 3 & & & 3 & 4 \\
\hline 3.Kekompakan kelompok & 4 & & & & 4 & 4 \\
\hline 4.Kreatifitas mengeluarkan pendapat & & 3 & & & 3 & 4 \\
\hline 5.Menghargai pendapat kelompok lain & & 3 & & & 3 & 4 \\
\hline \multicolumn{7}{|l|}{ Kegiatan Akhir } \\
\hline 1. Menarik Kesimpulan & 4 & & & & 4 & 4 \\
\hline 2. Evaluasi Akhir & 4 & & & & 4 & 4 \\
\hline Jumlah & & & & & 33 & 36 \\
\hline Skor Maksimal & & & & & 36 & \\
\hline Presentase & & & & & $92 \%$ & \\
\hline Keterangan & & & & & Sangat baik & \\
\hline Indikator ketercapaian $85 \%$ & & & & & & \\
\hline
\end{tabular}

Hasil observasi yang tercapai adalah 92\% dengan indikator ketercapaian $85 \%$ maka kriteria aktivitas dalam kualitas pembelajaran adalah sangat baik. Kesiapan siswa untuk mengikuti proses pembelajaran disebabkan adanya kesiapan alat dan bahan yang digunakan pada proses eksperimen. Siswa terlihat adanya kekompakan dalam kelompok belajar dan lebih aktif pada saat proses belajar berlangsung selanjutnya siswa mampu menarik kesimpulan secara logis dan sistematis sehingga dapat merumuskan dan menarik kesimpulan sendiri penemuannya dengan penuh percaya diri.

Penerapan strategi inkuiri dalam setting pembelajaran kooperatif siswa mampu berpikir sistematis, kritis, logis, analitis karena selama kegiatan pembelajaran siswa dilatih untuk dapat mencari dan menemukan sendiri materi pelajaran sedangkan guru berperan sebagai fasilitator dan pembimbing siswa untuk belajar dan mampu bekerja sama dengan anggota kelompok sehingga pengetahuan siswa lebih banyak karena adanya saling interaksi dan bertukar pikiran dengan siswa lain. Hasil penelitian ini sesuai dengan penelitian yang dilakukan Johnson dalam Nurhadi (2004) yaitu terdapat beberapa keunggulan dalam pembelajaran kooperatif antara lain memudahkan siswa dalam menyesuaikan perilaku sosial, menghilangkan sifat mementingkan diri sendiri dan mengembangkan kemampuan berpikir divergen atau berpikir kreatif. Aktivitas belajar adalah kegiatan belajar yang lebih bersifat aktif karena ada sejumlah proses mental yang dilakukan siswa. Kegiatan belajar ada beberapa bentuk misalnya bertanya jawab, diskusi, melakukan pengamatan, mendengarkan, mencatat, membaca serta mengerjakan tugas-tugas yang diberikan guru (Ibrahim dan Nana Syaodih, 1996).

Observasi kualitas pembelajaran guru yang dilakukan pada saat kegiatan pembelajaran berlangsung adalah untuk mengetahui sejauh mana pencapaian pengembangan guru pada penerapan strategi inkuiri dalam setting kooperatif. Indikator pencapaiannya kegiatan guru yaitu 81 dari jumlah secara keseluruhan mendapat predikat sangat baik. Adapun tabel 2 data kualitas pembelajaran guru penerapan strategi inkuiri dalam setting kooperatif sebagai berikut. 
Tabel 2 Data aktifitas guru dalam pembelajaran

\begin{tabular}{|c|c|c|c|c|c|c|}
\hline \multirow{2}{*}{ Aspek yang dinilai } & \multicolumn{4}{|c|}{ Kriteria Penilaian } & \multirow{2}{*}{ Skor } & \multirow{2}{*}{$\begin{array}{c}\text { Skor } \\
\text { Maksimal }\end{array}$} \\
\hline & 4 & 3 & 2 & 1 & & \\
\hline \multicolumn{7}{|l|}{ Kegiatan Awal } \\
\hline 1. Membuka pelajaran & & 3 & & & 3 & 4 \\
\hline 2. Memberi motifasi & & 3 & & & 3 & 4 \\
\hline 3. Memberi Apersepsi & & 3 & & & 3 & 4 \\
\hline \multicolumn{7}{|l|}{ Kegiatan Inti } \\
\hline 1. Penyampaian materi & & 3 & & & 3 & 4 \\
\hline 2. Memfasilitasi siswa & 4 & & & & 4 & 4 \\
\hline $\begin{array}{l}\text { 3. Memberikan materi untuk } \\
\text { didiskusikan oleh kelompok }\end{array}$ & 4 & & & & 4 & 4 \\
\hline $\begin{array}{l}\text { 4. Membimbing dan mengarahkan } \\
\text { siswa memecahkan materi. }\end{array}$ & & 3 & & & 3 & 4 \\
\hline $\begin{array}{l}\text { 5. Memberikan pertanyaan yang } \\
\text { sifatnya membangun siswa. }\end{array}$ & & 3 & & & 3 & 4 \\
\hline \multicolumn{7}{|l|}{ Kegiatan Akhir } \\
\hline 1. Menarik Kesimpulan & 4 & & & & 4 & 4 \\
\hline 2. Evaluasi Akhir & 4 & & & & 4 & 4 \\
\hline Jumlah & & & & & 34 & 40 \\
\hline Skor Maksimal & & & & & 40 & \\
\hline Persentase & & & & & 85 & \\
\hline Keterangan & & & & & $\begin{array}{c}\text { Sangat } \\
\text { baik }\end{array}$ & \\
\hline
\end{tabular}

Peningkatan skor siswa dalam merumuskan masalah disebabkan siswa mulai memahami langkah-langkah inkuiri khususnya merumuskan masalah dengan benar, hal ini terbukti bahwa siswa mampu melihat pentingnya masalah dan ketepatan merumuskan masalah. Strategi inkuiri pada dasarnya menekankan pada proses mencari dan menemukan sendiri sedangkan guru berperan sebagai fasilitator dan pembimbing siswa untuk belajar dan memberikan pertanyaanpertanyaan yang sifatnya membangun atau memberikan arahan-arahan kepada siswa untuk menemukan sendiri rumusan masalah karena belajar dengan cara menemukan sendiri akan lebih mudah diingat dan ditransfer untuk memecahkan masalah. pembelajaran kooperatif juga dituntut dalam merumuskan masalah karena memaksimalkan kerja dalam kelompok sehingga antar individu yang satu dengan yang lainnya saling berinteraksi dan komunikasi, hal ini terbukti siswa lebih aktif dalam kelompok, suasana kelas dan kelompok lebih kondusif sehingga saling berinteraksi untuk menemukan jawaban yang benar dan dapat dipertanggungjawabkan.

Merumuskan masalah merupakan langkah membawa siswa pada suatu masalah atau persoalan yang mengandung teka-teki. Dikatakan teka-teki dalam rumusan masalah yang ingin dikaji karena masalah itu tentu ada jawabannya dan siswa didorong untuk mencari jawaban yang tepat. Proses mencari jawaban itulah yang sangat penting dalam strategi inkuiri, oleh sebab itu melalui proses tersebut siswa akan memperoleh pengalaman yang sangat berharga sebagai upaya pengembangan mental melalui proses berpikir (Oimhim,2008).

Guru merupakan salah satu penentu keberhasilan siswa dalam KBM. Guru dalam melaksanakan kegiatan pembelajaran memberikan kontribusi yang positif agar siswa lebih fokus pada 
materi yang diajarkan sehingga hasil belajar siswa dapat mencapai tujuan yang ditetapkan. Menurut pendapat Grasser (dalam Hamzam B. Uno, 2006), terdapat empat hal yang harus dikuasai guru yakni menguasai bahan pelajaran yaitu 1) kemampuan mendiagnosi tingkah laku siswa, 2) kemampuan melaksanakan proses pengajaran dan 3) kemampuan mengukur hasil belajar siswa. Guru sebagai pelaksana kegiatan pembelajaran mampu menciptakan kondisi dan suasana kelas yang efektif dan kondusif sehingga siswa merasa nyaman dan lebih mudah dalam memahami materi yang disajikan oleh guru dan diharapkan dapat memberikan hasil belajar yang lebih baik. Menurut Made Pidarta (1991) aspek-aspek pengelolaan dalam pengajaran ialah menciptakan dan mempertahankan lingkungan internal yang mendorong dan merealisasi potensi manusia dan yang memberi kemungkinan kepada siswa bekerja sama dalam kelompok kelas untuk mewujudkan tujuan pendidikan secara efektif dan efisien.

\section{SIMPULAN}

Berdasarkan hasil penelitian dapat disimpulkan bahwa penerapan strategi inkuiri dalam setting pembelajaran kooperatif dapat meningkatkan hasil belajar siswa kelas VIII A SMPN I Geneng Ngawi pada proses merumuskan masalah, merumuskan hipotesis, melakukan eksperimen, mengumpulkan data, menarik kesimpulan dan aktifitas belajar siswa dan guru.

\section{SARAN}

Siswa dalam pelaksanaan kegiatan pembelajaran dituntut lebih kreatif untuk mencari dan menyelidiki sesuatu secara sistematis, kritis, logis, analitis sehingga mereka dapat merumuskan sendiri penemuannya dengan penuh percaya diri. Diharapkan dilakukan penelitian lebih lanjut untuk mata pelajaran lain sehingga dapat menjadikan siswa dapat mengambangkan konsep metodologis.

\section{DAFTAR PUSTAKA}

Hamzah B Uno. 2006. Orientasi Baru Dalam Psikologi Pembelajaran. Jakarta : Bumi Aksara.

Ibrahim dan Nana Syaodih. 1996. Perencanaan Pengajaran. Jakarta: Rineka Cipta.

Made Pidarta. 1991. Pengelolaan Kelas. Surabaya: Usaha Nasional.

Nurhadi. 2004. Kurikulum 2004. Jakarta: PT. Gramedia

Oimhim. 2008. Model Pembelajaran Inkuiri. (online) (http://Oimhim87. blogspot.) diunduh Maret 2009).

Sugiyanto. 2007. Pendidikan Dan Latihan Guru (PLPG) Model-Model Pembelajaran Inovatif. Surakarta: UNS.

Tatag Yuli Eko Siswono. 2009. Penulisan laporan penelitian untuk jurnal. Makalah disajikan dalam seminar Inovasi Pembelajaran Melalui Penelitian Tindakan Kelas, pusat seminar IKIP PGRI MADIUN, Madiun 25 Januari 2009.

Wina Sanjaya. 2006. Strategi Pembelajaran Berorientasi Standart Proses Pendidikan. Jakarta: Kencana. 